\title{
A Study on the Introduction of IT-Welfare Convergence Services
}

\author{
Ki-Min Song ${ }^{1}$, Seung-Il Moon ${ }^{2 *}$, Young-Min Song ${ }^{3}$, Joo-Suk Park ${ }^{4}$ and Seung- \\ Hoon $\mathrm{Han}^{5}$ \\ ${ }^{12}$ Hanyang University, Seoul, Korea \\ \{haieung, moonsi921*(Corresponding Author)\}@ hanyang.ac.kr \\ ${ }^{3}$ Anyang University, Incheon, Korea \\ songymin@anyang.ac.kr \\ ${ }^{4}$ Seokyeong University, Seoul, Korea \\ Ju310@hanmail.net \\ ${ }^{5}$ Honam University, Jeolla, Korea \\ shhan@honam.ac.kr
}

\begin{abstract}
Present welfare system is segmented, decoupled, inefficient, analogue, and insufficient for the safety welfare such as danger of dying alone in the ageing society. Construction of welfare infrastructure by using IT technology and related on-and offline combination welfare service system is required. Constitution of an independent "(tentatively named) Future Health and Welfare IT Fusion Support Center," which would integrate, control and link various social welfare services and which would function as a total professional control-tower is suggested. With the industrialization of ICT in order to meet the changes in the welfare environment in an ageing society and the diversification of welfare needs, present social welfare service delivery system would be changed into user-oriented one.
\end{abstract}

Keywords: Ageing Society, IT-Welfare Fusion Service, Network Construction, Service System, IT-Welfare Convergence Communication Service, Welfare Facilities for Senior Citizens, Automated System

\section{Introduction}

Elderly population, aged 65 or older, comprised $11.8 \%$ of the Korea's population in 2012, a percentage that is forecast to increase continuously from $3.1 \%$ in 1970 to $24.3 \%$ by 2030 , and to $37.4 \%$ by 2050 . In particular, the senior citizens living alone are increasing that $13.6 \%$ of the elder population lived alone in 1994, and $20.1 \%$ in 2009 . National Statistic Office reports that elderly single household would increase sharply from 1,020,000 households in 2010 to 1,510,000 in 2020, and 2,340,000 in 2030. Despite the changes in the welfare environment including low fertility and ageing population, present national health welfare still emphases basic necessities such as food, clothing, and shelter. Safety of senior citizens living alone, such as danger of dying alone, becomes a prominent issue for the social welfare in an ageing society[1],[2],[3].

Social welfare delivery system is one of the major governmental agents to deliver various welfare services to those who in need and to guarantee basic life-care. Its effective and timely delivery system is highly required. Present welfare delivery system of Korea is composed of public delivery system by central and local government; and private one by social welfare facilities and organizations, corporation, hospital, and individuals. Welfare services of Korea has been dominated by the central government, especially Ministry of Health and Welfare, but with the spread of regionalization, local government takes major role. And user-oriented welfare service and inter-ministerial 
association and cooperation among Ministry of Commerce, Industry and Energy, Ministry of Environment, or Ministry of Education and Science Technology is opportune. Therefore, efficiency of welfare delivery system, which is now separately operated by central and local government, social welfare facilities and association, corporation, and hospital, should be improved by using ICT as a key welfare delivery agent.

In this study, establishment of tentatively named "Future Health and Welfare IT Fusion Supporting Center" is suggested. It would a professional control tower to integrate, control and associate various dispersed social welfare services. ICT industrialization would change present welfare delivery system into a user-oriented one so as to adapt to the changing welfare environment in an ageing society and to meet the various welfare needs.

\section{Social Welfare Delivery Infrastructure and Network Construction by IT Technology}

Welfare facilities for seniors are professional facilities to tend dementia elders and geriatric patients, and it shows a continuous increase. National Statistic Office reports that welfare facilities for seniors increased about 14 percent from 60,769 in 2007 to 70,618 in 2011 , and its population doubled from 87,812 in 2007 to 158,839 in 2011. Its oversupply caused disparity in the facility environment and service quality, and increases dissatisfaction of the users. Interest in the nursing (welfare) facilities for seniors is increasing, but its management scheme is insufficient. Infrastructure construction and living environment improvement in order to decrease environmental, health, and safety danger for the most vulnerable members of society like Application of IT technology would change present offline welfare services provided by the Ministry of Health and Welfare into high-tech welfare services associated with the Ministry of Knowledge Economy. "Future Health and Welfare IT Fusion Support Center," the control-tower in charge of future online-offline health welfare service delivery system, would provide welfare products and services of the IT corporations. Above all, it would plan and manage IT services concerning health welfare with university, corporation, and day-care center; investigate and monitor the needs of the users; and merge the results to the technical development by university and corporate so as to promote manufacturing[4].

Construction of welfare delivery infrastructure and network using IT technology, and construction of merged on- and off-line business service system would promote the efficiency of the welfare. Application of medical services and cutting edge IT technology onto the present welfare service facilities would contribute to the development of services enhancement system. In order to promote the efficient welfare service, IT technology is applied to existing welfare delivery system. Various social welfare services all over the nation would be integrated, controlled, and linked by the IT welfare delivery system from the total professional control-tower. It would promote national awareness and increase welfare service delivery efficiency. 
Table 1. Current Status of the Welfare Facilities for Seniors

\begin{tabular}{|c|c|c|c|c|c|c|c|}
\hline \multirow[b]{2}{*}{ Category } & \multirow[b]{2}{*}{$\begin{array}{l}\text { Fa } \\
\text { cil } \\
\text { iti } \\
\text { es }\end{array}$} & \multicolumn{2}{|c|}{2011} & \multicolumn{2}{|c|}{2010} & \multicolumn{2}{|c|}{2009} \\
\hline & & $\begin{array}{l}\text { Facility } \\
\text { Number }\end{array}$ & $\begin{array}{l}\text { Populati } \\
\text { on }\end{array}$ & $\begin{array}{c}\text { Facilit } \\
\text { y } \\
\text { Numb } \\
\text { er }\end{array}$ & $\begin{array}{l}\text { Populati } \\
\text { on }\end{array}$ & $\begin{array}{c}\text { Facilit } \\
\text { y } \\
\text { Numb } \\
\text { er }\end{array}$ & $\begin{array}{l}\text { Populati } \\
\text { on }\end{array}$ \\
\hline $\mathrm{Su}$ & & 70,643 & 158,839 & 69,237 & 163,136 & 66,854 & 130,421 \\
\hline $\begin{array}{l}\text { Welfare } \\
\text { Facility } \\
\text { for } \\
\text { Housing }\end{array}$ & $\begin{array}{c}\text { Su } \\
\text { bt } \\
\text { ota } \\
1\end{array}$ & 414 & 17,450 & 397 & 17,270 & 360 & 14,353 \\
\hline $\begin{array}{l}\text { Welfare } \\
\text { Facility } \\
\text { for } \\
\text { Medical } \\
\text { Services }\end{array}$ & $\begin{array}{c}\mathrm{Su} \\
\text { bt } \\
\text { ota } \\
1\end{array}$ & 4,079 & 125,305 & 3,852 & 131,074 & 2,712 & 99,350 \\
\hline $\begin{array}{l}\text { Welfare } \\
\text { Facility } \\
\text { for } \\
\text { Leisure }\end{array}$ & $\begin{array}{c}\text { Su } \\
\text { bt } \\
\text { ota } \\
1\end{array}$ & 63,375 & & 62,469 & & 61,055 & \\
\hline $\begin{array}{c}\text { Welfare } \\
\text { Facility } \\
\text { for Home } \\
\text { Care }\end{array}$ & $\begin{array}{c}\text { Su } \\
\text { bt } \\
\text { ota } \\
1\end{array}$ & 2,750 & 16,084 & 2,496 & 14,792 & 2,696 & 16,718 \\
\hline $\begin{array}{l}\text { Special } \\
\text { Organizati } \\
\text { on for the } \\
\text { Protection } \\
\text { of the } \\
\text { Elders }\end{array}$ & $\begin{array}{c}\text { Su } \\
\text { bt } \\
\text { ota } \\
1\end{array}$ & 25 & & 23 & & 21 & \\
\hline
\end{tabular}

Source: Statistics Data of Ministry of Health and Welfare

Of the infrastructure networks using IT technology, the IoT (Internet of Things) technology is being actively applied in the medical service sector because it can realize medical cost reduction and medical quality improvement at the same time. This makes it possible to enhance the accessibility to welfare related information and to manage welfare users in real time, and enables real-time management through network such as health and safety support of the elderly based on smart technology. 


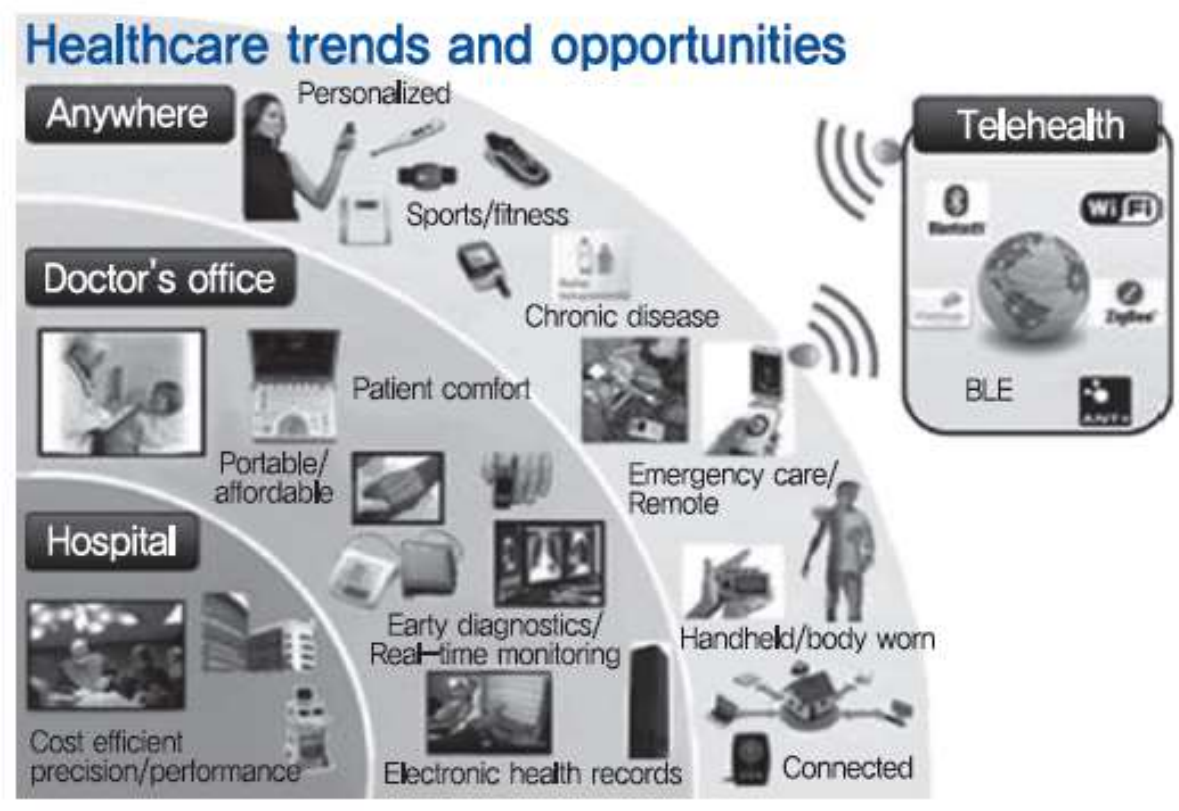

Figure 1. Trend of the Convergence between loT and Healthcare Industry

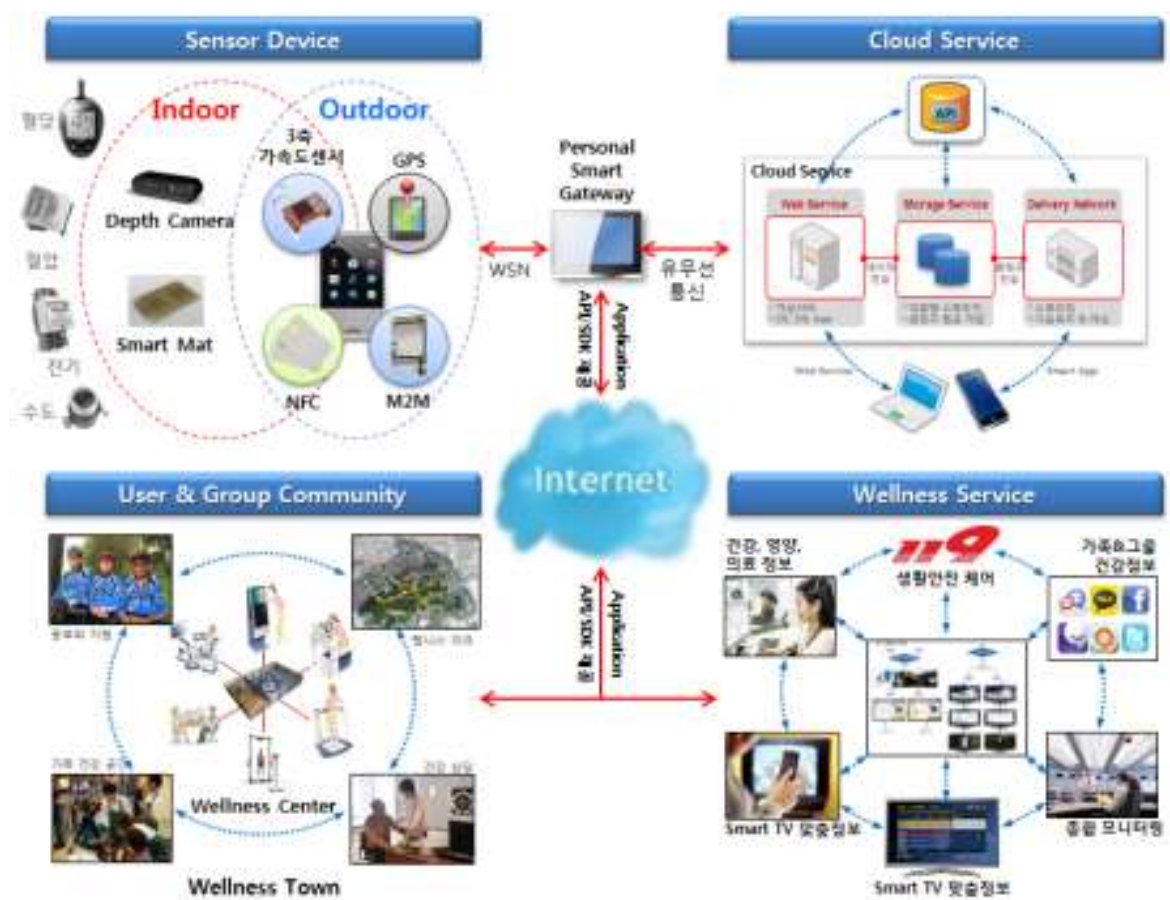

Figure 2. Example of High-Tech IT Health Welfare Services

\section{Bridge Making for Elder-friendly IT Welfare Industry}

When it comes to growth rate of ICT industry and its importance in GDP, ICT industry is emerging as the leading industry, forming 8.6 percent of GDP of Korea in 2010. But, looking on the tendency in the first half of the 2000's, its growth rate has been slower until 2009. Comparing with GDP growth representing macroeconomic, ICT industry highly contributes to the GDP growth by more than 20 percent. Importance of ICT 
industry in GDP declined slightly second-quarter in 2011 down to 7.5 percent, but its contribution rate is 0.8 percent $\mathrm{p}$, comprising 22.8 percent of GDP growth rate of 3.4 percent.

There have been many changes as IoT among the ICT industries has been spreading, resulting in much progress in advanced foreign countries. Looking at the growth possibility by industry of overseas IoT , the service market is expanding around public safety and retail until 2013. In the future, it will expand not only in the fields of healthcare and smart energy, but also in intelligent transport services, social infrastructure (transportation, bridges, etc.) remote management services etc.

\section{Table 2. Predictable Growth by Overseas IoT Industry (Unit: 100 million Dollar)}

\begin{tabular}{|c|c|c|c|c|c|c|c|c|}
\hline 구분 & 2011 & 2012 & 2013 & 2014 & 2015 & 2016 & 2017 & CAGR\% \\
\hline $\begin{array}{l}\text { Public Safety \& } \\
\text { Urban Security }\end{array}$ & 7.9 & 13.8 & 21.6 & 28.7 & 34.9 & 41.8 & 48.7 & 28.7 \\
\hline Retail & 8.8 & 15.3 & 34 & 32.0 & 38.9 & 46.5 & 54.2 & 28.8 \\
\hline Healthcare & 4.0 & 6.9 & 10.6 & 14.0 & 16.7 & 19.5 & 22.4 & 26.6 \\
\hline Energy \& Power & 2.6 & 4.8 & 7.8 & 10.7 & 13.5 & 16.8 & 20.6 & 33.8 \\
\hline Transportation & 2.0 & 3.9 & 6.7 & 9.8 & 12.9 & 16,6 & 20.5 & 39.5 \\
\hline Telecom \& IT & 5.3 & 9.2 & 14.3 & 18.9 & 22.6 & 26.5 & 30.3 & 27.0 \\
\hline $\begin{array}{c}\text { Consumer \& } \\
\text { Residential }\end{array}$ & 6.2 & 10.5 & 16,1 & 21.2 & 25.4 & 30.0 & 34.5 & 26.9 \\
\hline $\begin{array}{c}\text { Industrial \& } \\
\text { Commercial Buildings }\end{array}$ & 3.3 & 6.0 & 9.6 & 13.2 & 16.5 & 20.5 & 24.9 & 33.0 \\
\hline Manufacturing & 2.4 & 4.5 & 7.2 & 10.1 & 12.6 & 15.8 & 19.6 & 34.4 \\
\hline Others & 1.5 & 29 & 4.8 & 6.8 & 8.9 & 11.3 & 14.2 & 37.6 \\
\hline Total & 44.0 & 77.7 & 122.7 & 165.3 & 202.8 & 245,2 & 290.0 & 30.1 \\
\hline
\end{tabular}

As IoT is growing, the paradigm of healthcare services is changing toward the emphasis on prevention and management rather than treatment of diseases and IoT is actively applied to the healthcare sector because it can realize the reduction in medical cost and medical quality enhancement at the same time. Collection and utilization of biometric information through constant monitoring at home enable preventive health care and customized disease treatment, making it possible to reduce medical costs and improve the quality of medical care at the same time.

In addition, personalized services based on IoT health care that can be provided using various wearable sensors / devices are expected to provide personalized healthcare services such as heart disease management, diabetes management, hypertension management, and exercise tracking through Smartphone, Body Composition Monitor, Activity Monitor, Blood Pressure Monitor, Medication, Oxygen Saturation Monitor, Blood Sugar Monitor with the biometric information measured from various kinds of wearable sensors. 


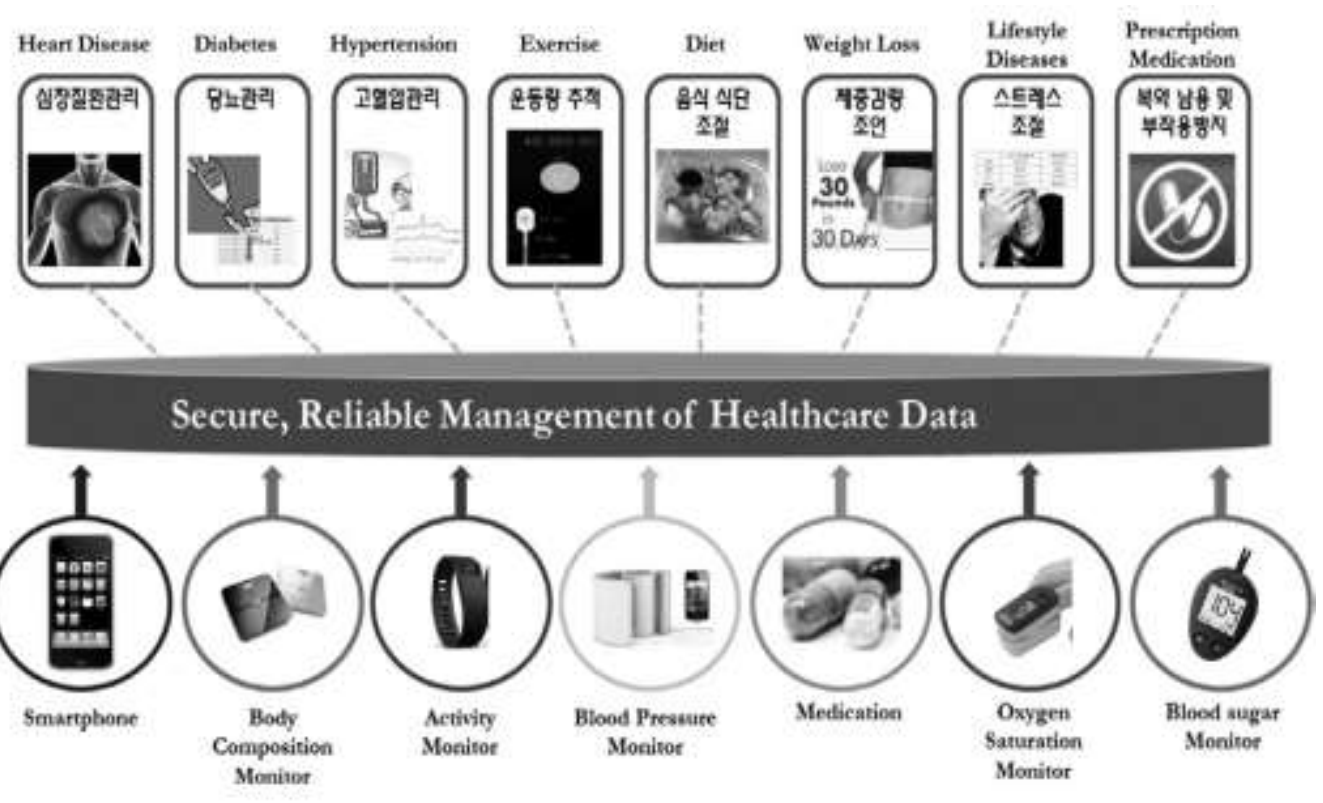

Figure 3. IoT Healthcare based on Personalized Service

Market for new IT products, developed or under development, would be secured by elderly day-care center. With this, new welfare IT services would be proposed so as to vitalize BC2 market for health welfare IT products and services. With the expansion of existing welfare service facilities, elderly day care center to meet various needs of the senior citizens would be provided. Sensing devices and other information devices would collect active senior citizens' physical activity information at home and provide it to elderly day care center. Various playing and gaming programs at the center would promote their healthier life. It is a combination of community center for senior citizens and senior welfare center. 


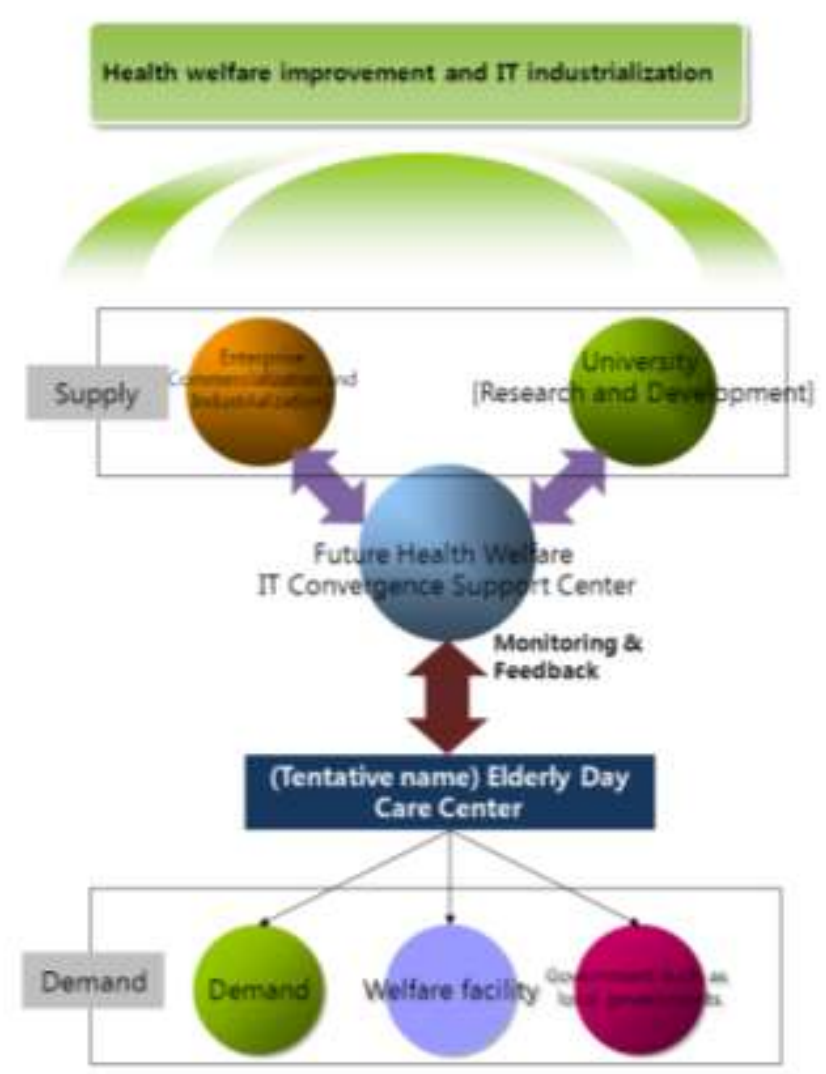

\section{Figure 4. Health Welfare Improvement and IT Industrialization}

B2C Market for various high-tech IT products and services (e.g. RFID, sensing devices, functional game) developed by industry combined source technology is very restricted. Personal use of the high-tech IT devices and service is insignificant. Tentatively names "day care center for the elder" in order to realize new welfare IT service by present welfare service providers and to use high-tech IT technology is suggested.

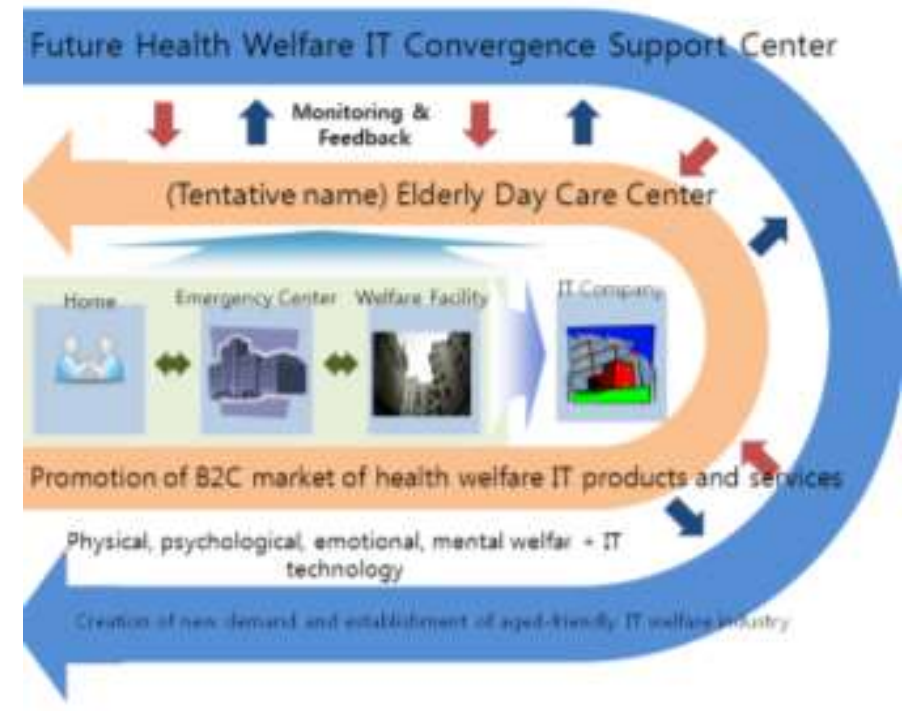

Figure 5. Future Health Welfare IT Convergence Support Center 
Personalized, emotion-based healing program, by analyzing personal health, body type, mental health status and by grafting a variety of IT technology onto present welfare, sports and leisure facilities, is proposed in order to promote health. Concerning resource use and cost efficiency, it is more efficient than creating day-care center for seniors currently ran by local welfare center. Customized life monitoring technology, which covers personal disease, motor ability, mental health status, is required. Off-line wellness center to counsel personal health, body type, worry of the elders, or knowledge system community for welfare and health by day-care center for the elder is suggested. Also, present off-line community health center and welfare center for the elders can be used as the health care complex for the aged, where physical and mental health of the elders can be examined at the elderly day-care center.

\section{Conclusion}

Improvement in efficient welfare service delivery system for the senior citizens as well as socially vulnerable classes including the disabled is required. In order to change existing inefficient and overlapping welfare system into future IT health welfare services, IT fusion supporting system for the senior citizens and service model should be constructed. And IT technology should be introduced into the physical, psychological, emotional and mental welfare so as to realize future IT health welfare services. Analysis of personal health, body type, mental health collected at the elderly day care center, and various IT technology applied to existing welfare, sports, leisure facilities would provide customized, emotion based healing program so as to promote one's health[5][6].

Collaboration among related government ministries including Ministry of Health and Welfare, Ministry of Public Administration and Safety, Ministry of Commerce, Industry and Energy, and home, as well as dementia center, medical institution, safety agencies such as police and fire station is highly expected.

Improvement of welfare delivery system by IT technology would improve safety welfare satisfaction and welfare accessibility by improving health, medical, welfare service quality of the senior citizens living alone. The improvement of existing welfare delivery system would reduce social cost and increase economic efficiency. Also, it would open a new market for IT corporations and industry of social welfare and provide a new business model in aged society. Job creation, diverse development of the welfare IT industry, and improvement of the quality of life by the provision of high-tech welfare service is expected[7].

\section{References}

[1] S. J. Choi, "Issues in social policy for ageing society in Korea". MD World Medical Publishing Co, (2009).

[2] W.A. Friedlander \& R. Z. Apte, "Introduction to Social Welfare. Englewood Cliffs", NJ: Prentice-Hall, (1980).

[3] N. Gilbert \& P. Terrell, "Dimensions of Social Welfare Policy". 6th ed. MA: Pearson Education, Inc, (2005).

[4] K. G. Provan \& P. Kenis, "Modes of Network Governance: Structure, Management, and Effectiveness", Journal of Public Administration Research and Theory. Vol. 18, (2007), pp. 229-252.

[5] J. H. Schulz, "The evolving concept of "retirement": Looking forward to the year 2050", International Social Security Review, vol.55, no.1, (2002), pp. 85-105.

[6] M. Shafritz, "The Facts On File: Dictionary of Public Administration", New York: Facts On File Publications, (2002).

[7] A. Walker, "A Strategy for active ageing", International Social Security Review, vol. 55, no.1, (2016), pp.121-139. 


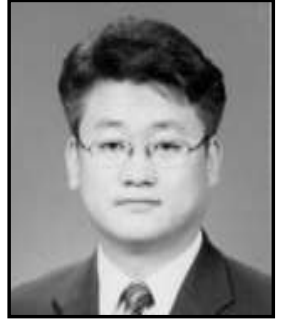

Ki-Min Song, is a professor of Hanyang University and Director of R\&SD Strategy Center. He has a lot of interest in Medical and Convergence industry. He has published many papers of these fields and given lectures for years. He received bachelor's and doctor's degrees in Hanyang University.

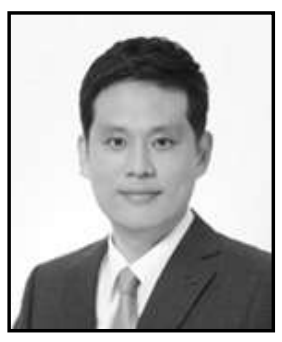

Seung-Il Moon, is a professor of Hospitality Academy in Hanyang University. He has a lot of interest in IT and information. He has written many papers and books on these fields and given lectures for years. He worked as a webmaster and Internet honorary national police officer.

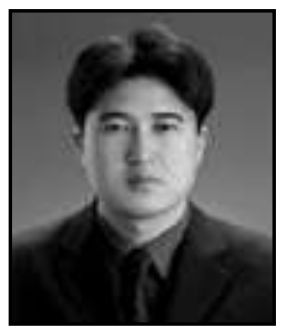

Young-Min Song, is an associate professor of Anyang University. $\mathrm{He}$ has a lot of interest in Serious Leisure and Convergence study. He has published many papers of these fields and given lectures for years..

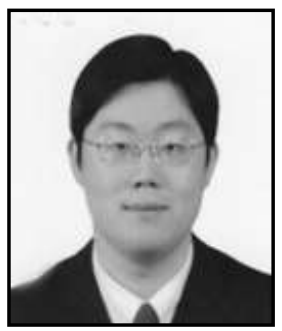

Joo-Suk Park, is a researcher in Seokyeong University. He is a former Korea National Open University lecturer. He worked in the area of IT \& administration law. He received a doctor's degree in University of Seoul.

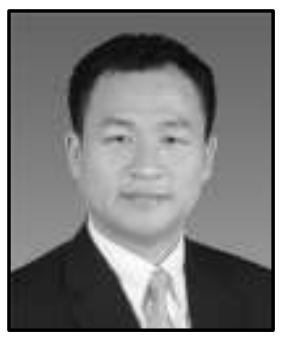

Seung-Hoon Han, is a professor of Honam University. He has a lot of interest in IT Service and Convergence study. He has published many papers of these fields and given lectures for years. 
International Journal of $u-$ and e- Service, Science and Technology

Vol.10, No.8 (2017) 